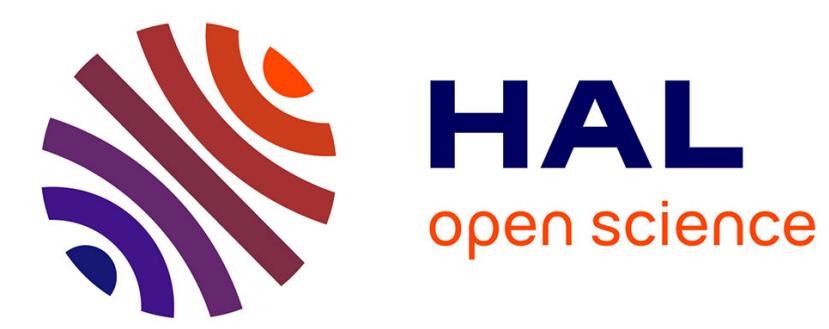

\title{
Determinants of FDI into China and Vietnam: A comparative study
}

Thi-Hong-Hanh Pham

\section{To cite this version:}

Thi-Hong-Hanh Pham. Determinants of FDI into China and Vietnam: A comparative study. 2012. hal-00671568

\section{HAL Id: hal-00671568 \\ https://hal.science/hal-00671568}

Preprint submitted on 17 Feb 2012

HAL is a multi-disciplinary open access archive for the deposit and dissemination of scientific research documents, whether they are published or not. The documents may come from teaching and research institutions in France or abroad, or from public or private research centers.
L'archive ouverte pluridisciplinaire HAL, est destinée au dépôt et à la diffusion de documents scientifiques de niveau recherche, publiés ou non, émanant des établissements d'enseignement et de recherche français ou étrangers, des laboratoires publics ou privés. 


\title{
Determinants of FDI into China and Vietnam: A comparative study
}

\author{
Thi-Hong-Hanh Pham*
}

2012/05

*LEMNA - Université de Nantes

EA 4272

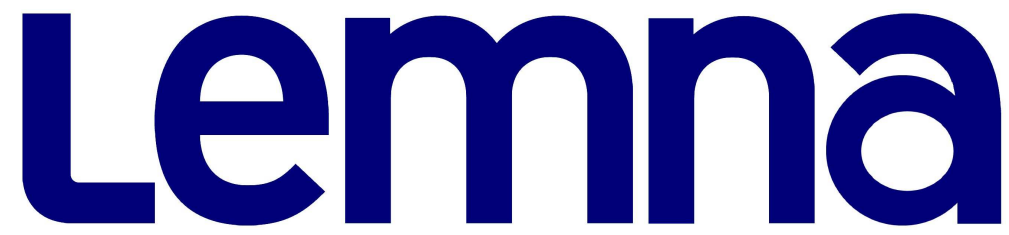




\title{
Determinants of FDI into China and Vietnam: A comparative study
}

\author{
PHAM Thi Hong Hanh \\ LEMNA, Institute of Economics and Management, University of Nantes \\ Chemin de la Censive du Tertre, BP 52231, 44322 Nantes Cedex 3, FRANCE \\ Phone: $+33(0) 240141733$ \\ Fax: +33(0)240141650 \\ E-mail: thi-hong-hanh.pham@univ-nantes.fr
}

\begin{abstract}
Since the inception of economic reforms, China in 1978 and Vietnam in 1986, both countries have become successful examples of transition to a market economy. Over their courses of reform, attracting substantial and rising amounts of inward FDI has been a key focus of their market-oriented policy reforms. Yet, the last two decades have experienced a widening gap in inward FDI between these two countries even though the context and characteristics of their economic reform are relatively similar. Therefore, this paper aims to address the question "What has caused the substantial gap in FDI inflows between China and Vietnam?" through a comparative study of the FDI determinants. In other words, this paper revisits the determinants of FDI into China and Vietnam by employing an augmented gravity model and using a panel dataset containing information on bilateral FDI and a large set of macroeconomic variables over the period 1994-2008. The main finding is that the widening gap in inward FDI flows between China and Vietnam can be explained by two broad sets of main factors: one related to institutions and another to domestic macroeconomic stability.
\end{abstract}

Keywords: Foreign direct investment; Gravity model; China; Vietnam

JEL: F15, F21, P20 


\section{Introduction}

FDI has become increasingly important in the developing world, and replaced the onwards official resource flows (ODA and loans from multilateral organizations) as the main source of external finance since 1994. By the end of 2006, the share of FDI inflows reached 51 percent of total capital flows to developing countries. Moreover, inward FDI stock in developing countries amounted for about one third of their GDP compared to just 10 percent in 1980 (UNCTAD, 2007). ${ }^{1}$ This worldwide trend has been seen as the most visible dimension of globalisation (Addison et al., 2006). Among others, China and Vietnam have recorded great achievements in attracting substantial and rising amounts of inward FDI. Inward FDI has become a determinant factor of China and Vietnam's economic growth as FDI is considered not only as a package of capital, technology and managerial skills, but also as an important source of both direct capital inputs and technology spillovers (Balasubramanyam et al., 1996; Li and Liu, 2005).

However, over the last twenty years, China and Vietnam have experienced a widening gap in the trend and patterns of inward FDI despite their similarities in economic and investment reforms. Therefore, the main objective of this paper is to address the question of which has caused the substantial gap in FDI inflows between China and Vietnam. To do so, we provide a comparative study of the determinants of FDI flows into China and Vietnam by employing an augmented gravity model that has been recently applied in a number of empirical studies of cross-country FDI activities.

On the other hand, since the beginning of the 1990s, China has become the most popular destination of FDI. This phenomenon results in another heated debate about whether China rivals its neighbouring economies in attracting inward FDI. In the related literature, a number of existing empirical studies suggest that China does not rival, however, may complement its Asian neighbours' FDI inflows. For instance, Eichengreen and Tong (2006) conclude the complementarity between FDI flows into China and those into other Asian economies. This finding is also supported by Zhou and Lall (2005) for a group of seven Asian economies over the period 1992-2001. Yet, to the best of our knowledge, no existing empirical study has been carried out to address the question of whether FDI in China have had a creation effect or a diversion effect on FDI flows into Vietnam. Thus, together with the main objective mentioned above, this paper also aims to fill this knowledge gap.

The remainder of this paper is organized as follows. Section 2 provides a literature survey on the determinants of FDI. It is followed by a brief outline of the trend and patterns of inward FDI in China and Vietnam over the last two decades (Section 3). Section 4 provides details about the econometric model and describes the panel dataset used for

\footnotetext{
${ }^{1}$ All developing economies excluding China
} 
the testing. Empirical results are reported and analysed in Section 5. Concluding remarks are in Section 6.

\section{FDI Determinants: A brief literature review}

Likely to the considerable theoretical work on FDI (e.g. Hymer, 1976; Hood and Young, 1984; and the OLI theory initialled by Dunning, 1977), determining key factors attracting FDI flows into a host country has been one of the most concerns in the international economics literature. Hundreds of existing scholarly works suggest that the factors determining FDI depend on the investor's different goals. First, the market-seeking investors are attracted to a host country with a large and fast growing local market. Second, with the aim of minimizing transportation costs and optimizing for locations with lower labour costs, the efficiency-seeking investors weigh more of geographical distance between the home country and the host country. Third, the abundant natural resources are the most important factor affecting the resource-seeking investors' decision. To the best of our knowledge, the large concerned literature has been surveyed on the orthodox survey of Blonigen (2005). Hence, deeply reviewing once again the literature of FDI determinants goes beyond the scope of this section. In light with the main objective of this paper, we only outline the most important and influent literature works shedding light on the determinants of FDI flows into China (2.1) and into Vietnam (2.2).

\section{Determinants of FDI into China}

Since the launch of economic reforms in 1978, China has recorded impressive achievements. Together with the strong rate of economic growth, growth in China's inward FDI has been even more remarkable. However, there are only a limited number of scholarly works on the determinants of inward FDI to China, although inward FDI plays an important role in fostering China's economic growth. In this regard, the factors determining FDI flows into China are classified into three categories: micro factors (concerning firm ownership specific advantages); macro factors (including market size, economic growth, institutional quality and so on); and strategic factors (referring to the long-term development strategy of the firm). In terms of macro determinants, Swain and Zhang (1997) and Liu et al. (1997) indicate that the real GDP growth rate significantly and positively influences inward FDI to China. Using a dataset covering FDI flows from

the US and Hong Kong to China, Zhang (2000) and Wei and Liu (2001) also support the positive relationship between market size and China's inward FDI.

Together with market size, the low level of labour cost factors is also one of the main determinants of China's inward FDI. This is confirmed in Swain and Wang (1995), who 
point out a positive relationship between China's relatively cheap labour and its inward FDI. Similarly, Liu et al. (1997) argue that the low wage rates are one of the most important economic factors determining China's inward FDI. Contrary to the importance of low wage rates in attracting FDI, Liu et al. (1997) find no evidence of the role of geographic factor in determining FDI into China. This finding seems to be not consistent with that of Grosse and Trevino (1996) implying that culture distance and geographic distance are significantly and negatively related to FDI inflows.

In another empirical research, Kerr and Peter (2001) examine the determinants of FDI flows into China over the period 1980-1998. Basing on the market imperfection framework and employing an error correction model, Kerr and Peter find that the wage level, the exchange rates, the interest rates level, the taxation regime and the openness degree of China's economy are the main determinants of inward FDI. Differing from Kerr and Peter (2001), who use a time-series dataset, Pan (2003) employs a panel dataset covering FDI flows from thirty home countries to China during 1984-1996 in order to investigate the impacts of country-specific factors on China's inward FDI. This work endeavours to explain the sharp decrease in FDI inflow to China due to the 1989 Tiananmen Square incident. Accordingly, some source country characteristics do not play any role in determining FDI flows into China because almost foreign investors are attracted to a large and fast growing local market of China. On the other hand, Pan (2003) also suggests that together with the aim of penetrating China's potential market, reducing transportation costs becomes another principal incentive for distant source countries to more invest in China. Basing on a smaller panel dataset covering bilateral FDI flow between China and its twenty-one home countries over 1983-1999, Zhao (2003) shows that the market-condition variables and the Yuan depreciation significantly increase FDI inflow to China, while the political and operating risks in China negatively influence its inward FDI.

Most recently, taking into account a sample of FDI inflows to China from 18 major donor countries during 1989-2006, Liu (2010) looks at the role of intellectual property rights (IPRs) protection as well as source-countries' macro variables in determining China's FDI inward. According to the author, the home countries with higher export ratio, depreciation of real exchange rate, lower borrowing cost, lower GDP per capita, higher relative labour cost, strong IPR protection and higher volatility in its exchange rate tend to invest more to China. To this end, basing on the empirical studies listed above, the main determinants of inward FDI to China can be classified into six sub-categories as also suggested in a survey work released by OECD (2000): (i) China's market size and 
economic growth performance; (ii) natural and human resource endowments; (iii) the infrastructure quality; (iv) the degree of trade openness and access to international markets; (v) the institutional quality; and (vi) the investment policies.

\section{Determinants of FDI into Vietnam}

The impressive growth of FDI flows into Vietnam has also become a growing concern in Vietnam's economic literature. While a large number of recent empirical studies investigate the triangular relationship between inward FDI, international trade and economic growth of Vietnam, there are only a few works examining the main determinants of FDI into Vietnam. In this vein, the pioneer work is developed by Nguyen and Haughton (2002), who investigate the impact of the US - Vietnam Bilateral Trade Agreement (BTA) on FDI flows into Vietnam. In order to simulate the BTA impact on Vietnam's inward FDI, the authors employ their estimated results of a FDI determinant model for sixteen Asian countries over the period 1991-1999. They find that the BTA could initially increase Vietnam's inward FDI by 30\% in the short run and twofold in the long-run. Lately, through a simple descriptive statistic analysis, Parker et al. (2005) study the trend and patterns of FDI flows into three Vietnamese industrial sectors, including clothing, furniture and fisheries, in which Vietnam records a strong export growth to the US since the BTA implementation. They conclude the important role of the Vietnam-US BTA in encouraging inward FDI to these three listed sectors that in turn results in a substantial increase in exports of FDI enterprises in Vietnam.

In a survey work, Mirza and Giroud (2004) tend to analyse the motivations of firms investing in Vietnam as well as identify several country-specific characteristics attracting FDI flows into Vietnam. Accordingly, political stability, government policies, local market size and quality of labour force have made Vietnam become a well-known destination on the world FDI map. More interestingly, the author show that $40 \%$ of FDI firms' output is for Vietnam's local market. However, according to Nguyen and Nguyen (2007), the contribution of Mirza and Giroud (2004) suffers many critical issues since it is based on a data sample quite small, only consisting of twenty-two foreign invested firms in Vietnam. Nguyen and Nguyen (2007) also provide an empirical analysis of the determinants of FDI spatial distribution across Vietnam's provinces. They argue that in terms of FDI provincial distribution, market size, labour force and infrastructure play an important role in attracting inward FDI to Vietnam. By contrast, government policy captured by the Provincial Competitiveness Index (PCI) does not seem to be a key FDI determinant at the provincial level.

Most recently, Pham (2011) empirically investigates the WTO accession's effect on Vietnam's foreign trade and inward FDI. The author concludes that WTO accession has a 
significantly positive effect on Vietnam's inward FDI. Pham (2011) also identifies two channels through which the WTO accession can positively affect FDI flows. Firstly, the WTO accession was expected to induce Vietnam to undertake further domestic reforms that would result in more predictable institutions and policies, as well as greater financial development. Greater financial development and a boom in banking activities made Vietnam's investment climate more attractive to foreign investors. Secondly, the WTO accession is expected to lead to the opening of services markets which in turn should include FDI flows into Vietnam. By and large, contrary to the significant contribution of inward FDI to Vietnam's economic development, the determinants of inward FDI have been still under-researched.

\section{Inward FDI to China and Vietnam: A simple comparative analysis}

Following the inception of economic reforms, the opening up of China and Vietnam to foreign investments began in 1979 with the implementation of the first Sino-foreign joint venture and in 1987 with the enforcement of the Law on Foreign Investment, respectively. Since then, all FDI activities in China and Vietnam had been regulated by these Laws together with their important amendments and additions. ${ }^{2}$ The progressive liberalization with important modifications to the investment law has made China and Vietnam succeed in attracting substantial and rising amounts of inward FDI. Thus, this section provides the main information on the trend and patterns of FDI flows (including the growth and the donor countries composition) into China and Vietnam since the launch of their economic reforms. ${ }^{3}$ On the other hand, we also endeavour to take a closer look at the possible factors responsible for the inward FDI divergence between China and Vietnam over the studied period.

\section{Inward FDI flows' growth}

Table 1 presents recent trends in FDI inflows both as a percent of GDP and as a percent of fixed capital formation. As reported in Table 1, before the 2000s, the world economy experienced a sharply increasing trend in inward FDI (using both measures). Precisely, FDI inflows during the 1990s increased to three or four times compared to the 1980s' FDI inflows. However, since the beginning of 2000s, there has been a lessening trend in inward FDI, especially during the period 2000-2004.

From Table 1, we can also observe that China and Vietnam's FDI inflows (in both measures) seem to show the same relative magnitudes and temporal dynamics as other countries in the region to which China and Vietnam belong. Yet, since 1990s, the

2 Information on Vietnam's investment law can be found at http://www.mpi.gov.vn/portal/page/portal/mpi_en; Information on China's investment law can be found at http://www.fdi.gov.cn/pub/FDI EN/default.htm.

${ }^{3}$ FDI sectoral and partial distribution is not included because it goes beyond the scope of this paper. 
contribution of inward FDI to economic growth and capital formation has been much more important in Vietnam than in China. It means that compared to China, Vietnam could be more vulnerable to an external shock coming from its FDI source countries. The last part of Table 1 also allows us to map the position of FDI flows into China and Vietnam. The fact is that Vietnam is only a little dot on the world FDI map while China has become the most popular destination of FDI.

\section{Table 1: World Distribution of FDI inflows}

\begin{tabular}{lrccccc}
\hline & & & & & & \\
& & & & & & \\
\end{tabular}

Source: Author's computations from WDI and $A D B$

We now turn our attention to the growth rate of FDI into China and Vietnam, which is plot in Figure 1. Interestingly, China and Vietnam reveal a very similar trend in growth rate of FDI inflows. At the beginning of 1990s, both China and Vietnam observed a massive inward FDI flow. The officially net FDI inflows over 1990-1994 rose from US\$ 348.7 million to US\$ 3.37 billion in China and from US\$ 180.0 million to US\$ 1.94 billion in Vietnam. A number of reasons backed this robust increase. First, foreign investors were attracted by the potentiality of a transitional economy with a great market remaining untapped. Second, they were also attracted by a series of other positive factors such as the abundant labour force, the cheap labour cost and the abundant natural resources as well. From 1997 to 1999, both China and Vietnam experienced an erratic growth rate of registered FDI, which was partially due to the Asian financial crisis. In fact, the main FDI donor countries of China and Vietnam were the Asian countries, who themselves had to face difficulties in their domestic markets. To maintain the domestic business operations, these donor countries had to postpone or cancel overseas expansion plans, in particular FDI projects. 
Figure 1: FDI growth rate 1991-2009

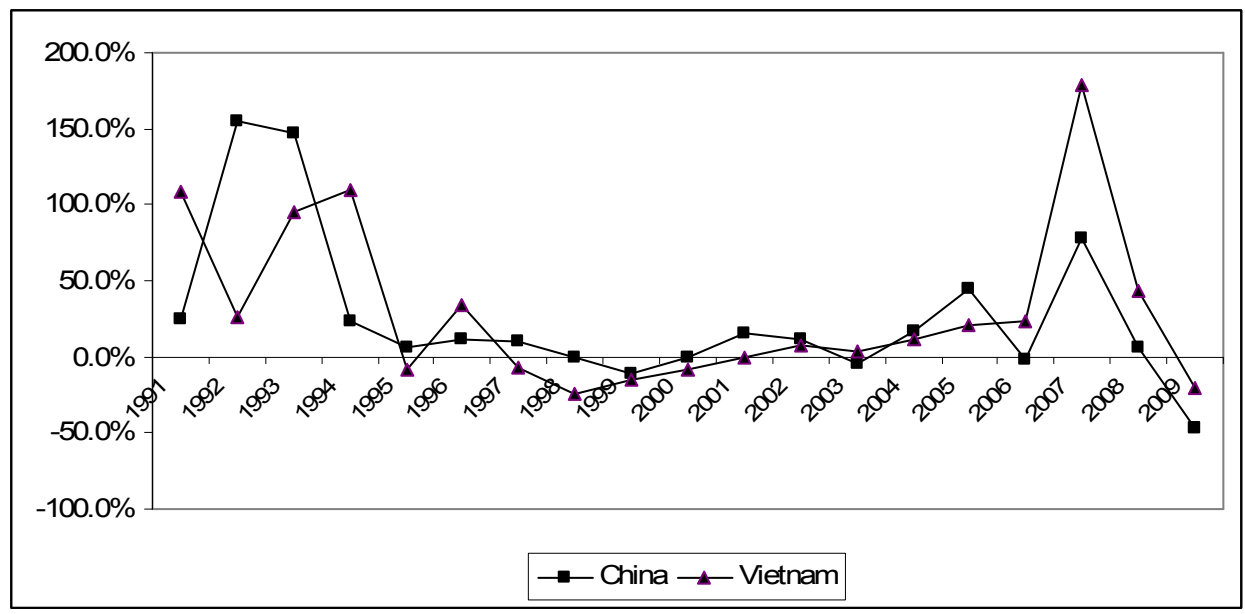

Source: Created from WDI

Over the period 2003-2005, China and Vietnam witnessed a strong comeback of FDI. For instance, by 2005, Vietnam attracted over US\$6.8 billion of newly registered FDI, rising by 50.1 percent. In 2007, Vietnam's WTO accession immediately had a positive impact on attracting FDI into the country. As expected, Vietnam's inward FDI tremendously grew to a high record of over US\$ 1943 million in the 2007 first quarter and increased by 155.6 percent compared to this figure of the same period in 2006. By the end of 2007, Vietnam's annual growth rate of inward FDI already reached 179.2 percent and almost tripled compared to 2006. During the same period 2006-2007, China also evidenced a remarkable recovery of inward FDI. However the growth rate of China's inward FDI in 2007 had not yet exceeded the highest record of $155.5 \%$ attained in 1992. After a massive surge of inward FDI in 2007, Figure 1 also shows a fall in net inward FDI to both countries over 2008-2009. This chute probably resulted from the unfavourable worldwide development context caused by the propagation of 2007 financial crisis.

\section{Inward FDI by source countries}

In terms of FDI sources, investors from over 150 and 80 different countries have invested in China and Vietnam, respectively. Table 2 lists the major FDI donor countries of China and Vietnam over the period $1994-2008$.

Comparing the structure of FDI inflows between China and Vietnam during the period under consideration, we find that the most important sources of FDI into China and Vietnam come from East Asia. Besides, the share of FDI from ASEAN to China is fairly small while ASEAN zone is the second important source of FDI into Vietnam. It means that the connectedness with other countries in the same economic zone may be an important factor explaining the FDI distribution. On the other hand, the contribution of FDI inflows from the world leader economy, the US, is much higher in China than in Vietnam. Finally, as reported in Table 2, China has tended to improve its FDI 
relationship with the rest of the world. This phenomenon is supported by a substantial increase in FDI inflows to China from the rest of the world. By contrast, strengthening the intra-regional financial integration (with East Asia and ASEAN countries) has seemed to be Vietnam's recent development strategy.

Table 2: China and Vietnam's main FDI source countries (in \%)

\begin{tabular}{ccccccc}
\hline \multirow{2}{*}{ China } & East Asia & ASEAN & EU15 & USA & Others \\
\hline \multirow{6}{*}{ Vietnam } & $1994-1999$ & 59.28 & 4.89 & 7.56 & 8.08 & 20.17 \\
& $2001-2004$ & 47.84 & 5.91 & 8.07 & 8.79 & 29.38 \\
& $2005-2008$ & 46.17 & 5.51 & 6.66 & 3.95 & 37.71 \\
\hline & & & & & & \\
& $1994-1999$ & 30.64 & 29.71 & 9.70 & 3.80 & 26.15 \\
& $2001-2004$ & 38.07 & 19.81 & 20.04 & 3.96 & 18.12 \\
\hline
\end{tabular}

Source: Author's computations from the database of National of Bureau of Statistics of China and Vietnam Ministry of Planning and Investment

Overall, the present section briefly outlines the trend and patterns of inward FDI to China and Vietnam. Yet, to gain a better understanding of the FDI determinants as well as to resolve the question of whether China's inward FDI can create or divert Vietnam's inward FDI, a formal empirical analysis will be provided in the next sections.

\section{Gravity equation setting and Data issues}

As mentioned in the introduction, to assess the main determinants of inward FDI to China and Vietnam, we apply the augmented gravity models. Even though there is no clear theoretical foundation for applying a gravity equation to explain FDI activity, many previous cross-country FDI studies have deployed this equation, in which FDI flows become an endogenous variable and is explained by the economic size of home and host countries, the geographic distance and many other macroeconomic variables.

In the concerned literature, a few recent studies aim to introduce a number of modifications to a standard gravity necessary to determine FDI patterns. Basing on the knowledge-capital model, Carr et al. (2001) and Bergstrand and Egger (2007) develop a theoretical model of multinational enterprise's (MNE) decisions, through which the authors introduce many additional possible factors explaining FDI patterns. Accordingly, the gravity variables, such as the geographic distance and the country size, allow one to explain "horizontal" FDI motivations, while "vertical" FDI motivations are captured by other explanatory variables such as labour endowments, natural resource abundance and so on. A gravity equation is also used in Head and Ries (2008) to model mergersacquisitions FDI motivations. This work supports the role of two other gravity variables, notably the common culture and language, in determining FDI patterns. 
In another recent work, employing a the Bayesian Model Averaging technique, Blonigen and Piger (2011) have introduced an appropriate set of potential FDI determinants that include a combination of covariates proposed by three studies listed above as well as other previous literature on FDI determinants (e.g. Eaton and Tamura, 1994; Di Giovanni, 2005). Therefore, the choice of gravity variables in our empirical model is based on the work of Blonigen and Piger (2011). Precisely, our two gravity equations are formulised as follows:

$$
\left\{\begin{array}{l}
F D I_{i t}^{C H N}=f\left(G R A_{t} ; I N D E_{-} V A_{t}\right) \\
F D I_{i t}^{V N M}=f\left(F D I_{i t}^{C H N} ; G R A_{t} ; I N D E_{-} V A_{t}\right)
\end{array}\right.
$$

where $F D I_{i t}^{C H N} / F D I_{i t}^{C H N}$ are implemented inward FDI to China and Vietnam from the country $i$ at the time $t$, respectively; $G R A_{t}$ is a set of standard gravity variables, including the geographic distance and the economic size of FDI host and home countries; and $I N D E_{-} V A_{t}$ is a group of independent variables that strongly correspond to those proposed by Blonigen and Piger (2011) with only a few exceptions.

- First, differing from Blonigen and Piger (2011), we include exchange rate variables to examine also the possible impact of dynamic and short-run changes in exchange rate on FDI inflows.

- Second, another main objective of this paper is to contribute to the debate on whether China competes with Vietnam for attracting inward FDI. To do so, we include in Vietnam's FDI gravity equation an additional variable, which is inward FDI to China from each of Vietnam's main FDI home countries.

- Third, we evaluate the potential impact of financial crisis on FDI decision by introducing in each regression equation a binary dummy. In order to determine the value of this dummy, we employ the work of Laeven and Valencia (2008), in which the authors present a new database on the timing of systemic financial and banking crises as well as policy responses to resolve them. This binary dummy takes the value of 1 if the FDI source country really suffers from a crisis over the studied period and value of 0 in the opposite case.

- Lastly, the relationship between inward FDI and international trade has been strongly evidenced in the literature. Thus, in all gravity equations we include bilateral trade flows between China/Vietnam and their FDI donor countries to revisit this linkage. However, simply including bilateral trade flows in the augmented FDI gravity equation could induce a potential problem of endogeneity. To tackle this issue, we employ two alternative estimators, notably the estimation proposed by Hausman and Taylor (1981) (henceforth, the HTM) and the 
Instrumental Variables (IV), which are widely known as a solution to endogenous regressors and provides a way to obtain consistent parameter estimates.

Appendix 2 summarises the dataset and provides the source of all variables of interest as well as their units of measurement. In general, inward FDI to China and Vietnam is mainly explained by a group of variables as follows:

Inward FDI $=\boldsymbol{F}$ (Bilateral trade flows between home and host countries;

GDP of FDI home and host countries;

GDP per capita of home and host countries;

Geographic distance between home and host countries;

Trade openness level of home country;

Average monthly wages of host country;

Degree of financial development of host country;

Bilateral real exchange rate between the home and host countries;

KAOPEN index of the home and host countries;

Average inflation of host country;

Institutional quality of host country)

We now turn our attention to the datasets used for the empirical testing. In this paper, we build two separate datasets over the period 1994-2008. The first one covers China's inward FDI from its forty-one major source countries. Second, due to an unavailability of Vietnam's data we can only provide a smaller dataset capturing FDI inflows to Vietnam from only seventeen home countries. ${ }^{4}$ Here, we use the realized FDI data for both China and Vietnam. The reason is that many foreign investors that invested in the host country during the period failed to register their projects in advance. This explains why the officially registered FDI cannot be used as a consistent and accurate measurement of FDI activities in the home country in rigorous studies. To this end, due to data unavailability, we must collect our panel data from various credible sources: the Ministry of Planning and Investment and General Statistics Office (GSO) of Vietnam; the National Bureau of Statistics of China; the Asian Development Bank (ADB); ASEAN Secretariat; the International Monetary Fund (IMF); and the United Nations Statistics Division (UNSD).

\section{Empirical results}

The econometric test is performed in two steps. First of all, we perform the HTM originally proposed by Hausman and Taylor (1981) to investigate the possible links between explanatory variables and inward FDI to China and Vietnam. In a series of seminal works of Egger (2000; and 2002b), the HTM technique is considered as the most appropriate estimation of cross-section gravity mode.

\footnotetext{
${ }^{4}$ FDI source countries of China and Vietnam are listed in Appendix 1.
} 


\begin{tabular}{|c|c|c|}
\hline \multirow[t]{2}{*}{ Explanatory variables } & \multicolumn{2}{|c|}{ Data samples } \\
\hline & China & Vietnam \\
\hline 1. Inward FDI to China & - & $0.06(0.06)$ \\
\hline 2. Exports to FDI home country & $0.16^{* *}(0.06)$ & $0.16(0.13)$ \\
\hline 3. Imports from FDI home country & $0.01(0.07)$ & $0.36 * *(0.17)$ \\
\hline 4. GDP of China/Vietnam & $2.59^{* * *}(0.83)$ & $1.53^{* * *}(0.31)$ \\
\hline 5. GDP of FDI home country & $0.46^{* * *}(0.17)$ & $0.50^{* *}(0.24)$ \\
\hline 6. GDP per capita of China/Vietnam & $2.48(2.75)$ & $0.14(2.80)$ \\
\hline 7. GDP per capita of FDI home country & $0.18(0.17)$ & $0.44(0.33)$ \\
\hline 8. Geographical distance & $-2.01^{* * *}(0.38)$ & $-1.35^{* *}(0.65)$ \\
\hline 9. Trade openness of FDI home country & $-0.00(0.00)$ & $1.02 \mathrm{e}-10^{* * *}(3.10 \mathrm{e}-11)$ \\
\hline 10. Average monthly wages & $1.72(2.20)$ & $1.62(1.35)$ \\
\hline 11. Financial development of China/Vietnam & $-2.52(2.55)$ & $-0.53(1.15)$ \\
\hline 12. Real exchange rate & $0.08 *(0.04)$ & $0.38^{* * *}(0.13)$ \\
\hline 13. KAOPEN index of FDI home country & $0.30^{* * *}(0.07)$ & $-0.33^{*}(0.15)$ \\
\hline 14. KAOPEN index of China/Vietnam & - & $0.79(1.75)$ \\
\hline 15. Average inflation of China/Vietnam & $-0.04(0.03)$ & $-0.14 * * *(0.02)$ \\
\hline 16. ICRG score of China/Vietnam & $1.51^{* * *}(0.49)$ & $0.14 * *(0.03)$ \\
\hline 17. Crisis dummy & $-0.19(0.00)$ & $-0.26^{*}(0.14)$ \\
\hline 18. Bilateral trade agreement & $-0.48(0.30)$ & $0.34 *(0.16)$ \\
\hline 19. WTO & $0.54(0.49)$ & $1.40^{* * *}(0.33)$ \\
\hline 20. Contiguous border & $-0.48(0.80)$ & $-0.75(2.53)$ \\
\hline Constant & $15.10(59.51)$ & $35.10(90.25)$ \\
\hline
\end{tabular}

Notes: Values in parentheses are robust standard errors. ${ }^{* * *},{ }^{* *}, *$ : Significant at 1 percent, 5 percent, 10 percent level respectively.

\section{The Hausman-Taylor estimator' results}

We begin with a discussion on the estimated coefficients of gravity variables reported in Table 3.1. First, we look at the possible impact of country size, which is measured by the level of GDP, on China and Vietnam's inward FDI. In both gravity equations, the positive and statistically significant value of FDI home country's GDP variable implies that inward FDI to China and Vietnam strongly depends on economic growth of their partner countries. Similarly, estimated coefficients of China and Vietnam's GDP are significantly positive, also implying that China and Vietnam's economic growth plays a determinant role in attracting FDI to the countries. However, the value of this coefficient in Vietnam's equation (1.53) is relatively smaller than that in China's equation (2.59). Contrary to the impact of GDP variables, we find that all GDP per capita variables have no impact on inward FDI either to China or to Vietnam. Second, in terms of other gravity variables, we 
find that the geographic distance, as expected, is significantly and negatively related to the FDI inflow, while the contiguous border variable does not exercise any impact on FDI flows into both countries.

We now focus on the role of bilateral trade flows in determining inward FDI. Following the empirical results, there is a positive link between China's inward FDI and its exports to FDI home countries, whereas Vietnam's import growth slightly encourages FDI inflows to the country. Two main comments on this result may be made. In the case of China, the period under consideration 1994-2008 experienced a memorable growth of China's exports that in turn had played an important role in attracting FDI inflow. Investing to China allows the foreign investors to benefit from an existing and large export market of China and then to re-export their products to the third markets as well as to their home country. In the case of Vietnam, the linkage from imports to inward FDI reflects foreign investors' confidence in Vietnam's emerging growth prospects. In other words, a rapid growth of imports reflecting a substantial economic growth in Vietnam has also become the main cause for the surge in its inward FDI.

Together with the previous empirical results, we also detect either differences or similarities between the impacts of other macroeconomic variables on China's inward FDI and those on Vietnam's inward FDI. First, trade openness level of FDI home countries is not a factor explaining their FDI flows to China while the coefficient of this variable is significantly positive but fairly small in Vietnam's FDI equation. Second, we find no evidence of a link between the average wages and inward FDI to both China and Vietnam. However, it does not means that China and Vietnam's relatively low labour cost has no impact on attracting FDI. Because, in order to fully detect the role of labour cost in determining inward FDI, other alternative and complementary measures should be required but unfortunately not available due to the data limitation of China and of Vietnam in particular. Third, the empirical finding does not offer any evidence of a positive connection running from the development of domestic financial market to inward FDI of both China and Vietnam. However, it is worth noting that over the economic reform courses, both China and Vietnam have recorded a substantial increase in the ratio of private credit (provided by the banking sector), which has been considered as the most used indicator of financial development (e.g. Rajan and Zingales, 2003; Baltagi et al., 2009). For instance, as reported in Table 4, over the studied period, the banking private credit of both China and Vietnam continues to grow rapidly and faster than the average value of all countries in the same region. So that, no correlation between financial development and inward FDI results in an open question about the 
effectiveness of financial deepening in China and Vietnam. We leave this issue for our further cross-sectoral analysis.

Table 4: Main macroeconomic indicators of China and Vietnam

\begin{tabular}{|c|c|c|c|}
\hline & \multicolumn{3}{|c|}{$\begin{array}{l}\text { Domestic credit provided by banking sector } \\
(\% \text { GDP })\end{array}$} \\
\hline & $1995-2000$ & 2001-2004 & 2005-2008 \\
\hline Vietnam & 22.47 & 46.68 & 84.45 \\
\hline China & 102.84 & 135.67 & 129.09 \\
\hline ASEAN (Average value & 58.26 & 55.23 & 63.75 \\
\hline \multirow[t]{3}{*}{ East Asia (Average value) } & 115.11 & 123.96 & 124.38 \\
\hline & \multicolumn{3}{|c|}{ Inflation rate } \\
\hline & $1995-2000$ & $2001-2004$ & 2005-2008 \\
\hline Vietnam & 9.38 & 4.83 & 11.46 \\
\hline \multirow[t]{3}{*}{ China } & 5.16 & 1.05 & 3.47 \\
\hline & \multicolumn{3}{|c|}{ GDP growth rate } \\
\hline & $1995-2000$ & $2001-2004$ & 2005-2008 \\
\hline Vietnam & 7.51 & 7.18 & 6.29 \\
\hline China & 9.12 & 9.18 & 11.95 \\
\hline
\end{tabular}

Source: Computed from WDI and ADB

Note: East Asia includes China, Hong Kong - China; Korea and Taiwan

Forth, regarding to the exchange rate variable, its estimated coefficient is positive in all gravity equations, implying that a depreciation of the Yuan and the Dong against the US dollar encourages FDI flows into China and Vietnam, respectively. Fifth, contrary to this finding, we find that the role of de jure financial openness in determining inward FDI varies between China and Vietnam. Remind that the de jure measure used in this paper is the Chinn and Ito (2006) index of capital account openness (KAOPEN index). The authors constructed this measure from four binary dummy variables that codify restrictions on cross-border financial transactions reported in the IMF's Annual Reports on Exchange Arrangements and Exchange Restrictions. Following the newest database constructed by Chinn and Ito, the KAOPEN index of China over the period 1994-2008 has been unchanged. That is why this paper fails in revealing the impact of this variable on China's inward FDI. Interestingly, China's inward FDI is significantly and positively influenced by the KAOPEN index of its FDI home country, meaning that more open economies to international finance are more attracted by China's economic performance and then more invest into China. This finding also suggests that establishing investment relationship with China seems to be requisite in the financial openness policy setting of the FDI donor countries due to China's important standing in the world economy. By contrast, the changes in KAOPEN index of FDI donor countries are not favourable to FDI flows into Vietnam. 
We now take a look at other macro domestic conditions, including the inflation rate and the institutional quality of each country. On one hand, inward FDI to Vietnam has negatively suffered from the accumulated inflationary pressures, especially during the recent period. As reported in Table 4, China has maintained a pretty low inflation rate compared to almost other developing economies, whereas Vietnam has experienced a decreasing trend in economic growth that is unfortunately followed by a high and drastically increasing inflation rate. Consequently, macroeconomic instability negatively influences Vietnam's inward FDI. Furthermore, another politic question arises about the role of Vietnam's institutional quality in attracting inward FDI, since the coefficient of ICRG score variable is significantly positive but much smaller in Vietnam equation than in China equation. In other words, in terms of institutional quality and compared to China, Vietnam has an unmatched advantage in attracting FDI inflows. Now looking at the estimated coefficients of domestic crisis dummy, we find a negative and significant value of this dummy in both China and Vietnam's estimation equations. It means that the domestic financial crisis of FDI donor countries had negatively influenced FDI flows into China and Vietnam. In other words, the macroeconomic context of FDI home countries can be considered as a main determinant of FDI into China and Vietnam.

Finally, we pay a special attention to the role of BTA as well as of WTO membership. First, we only find a positive effect of BTA on Vietnam's FDI inflows. The estimated coefficient of BTA variable is statistically significant at the 10 percent level, suggesting that the BTA promotes Vietnam's inward FDI. The result is consistent with the fact that BTAs have been implemented between Vietnam and its principal trading partners (including the US, Japan, EU15 and ASEAN). Second, regarding to the WTO variable, we find no evidence of a positive impact of becoming a WTO member on China's inward FDI, while joining the WTO strongly and positively affects Vietnam's inward FDI. This finding is consistent with that of Pham (2011), who points out two possible channels through which the WTO accession can influence Vietnam's inward FDI. On one hand, the WTO accession has been expected to induce Vietnam to undertake further domestic reforms that would result in more predictable institutions and policies, as well as greater financial development. The potential development of the financial system may be considered as one of the main causes for the surge in FDI flows into Vietnam. On the other hand, the WTO accession is also expected to lead to the opening of services markets that seems to be another primary cause for the surge of FDI into Vietnam in general and into services sectors in particular. 


\section{The IV estimator's results}

In the first step, the implement of assume that some of the explanatory variables are correlated with the individual-level random effects, but that none of the explanatory variables are correlated with the idiosyncratic error. According to Nickell (1981), this correlation can make the panel estimation equations suffer from the estimation bias. Among other methods, which can correct the country specific or time-specific effects and allows getting rid of any endogeneity in explanatory variables, the Instrumental Variables estimator is a preferred estimator. However, determining the IV in each estimated gravity equation is not an easy task. In this article, we have to instrument the export and import variables with two other external variables:

- Export variable from China or Vietnam is instrumented with the level of hidden import barriers of the destination countries;

- Import variable into China or Vietnam is instrumented with the level of hidden import barriers of China and Vietnam, respectively;

First of all, we test for the validity of each instrumental variable. In the lower part of Table 3.2, we report the weak instrument test suggested by Stock and Yogo (2002) and the Hansen/Sargan test of over-identifying restrictions. On one hand, in the weak instrument test the Cragg-Donald F-statistics are superior to the critical value of 10 percent maximal IV size proposed by Stock and Yogo (2002), meaning that the null hypothesis of weak instruments is rejected. On the other hand, the Sargan/Hansen test of over-identifying restrictions, which is reported in the last line, checks the validity of the instruments. According to the empirical results, we cannot reject the null hypothesis of Sargan/Hansen test meaning that the instruments are valid instruments, notably uncorrelated with the error term, and that the excluded instruments are correctly excluded from the estimated equation.

We now look at the IV estimator's main results reported in the upper part of Table 3.2. On the whole, we find that applying the IV technique to estimate all regression equations does not alter the sign or the statistical significance of explanatory variables, including openness variables. Only the magnitudes of estimated coefficients are little affected. It implies the IV estimator's results as effectively supportive of the robustness of the HTM results. 
Table 3.2: Instrumental Variable estimator's results

\begin{tabular}{|c|c|c|}
\hline \multirow[t]{2}{*}{ Explanatory variables } & \multicolumn{2}{|c|}{ Data samples } \\
\hline & China & Vietnam \\
\hline 1. Inward FDI to China & - & $0.04(0.13)$ \\
\hline 2. Exports to FDI home country & $0.73^{* *}(0.31)$ & $0.93(0.74)$ \\
\hline 3. Imports from FDI home country & $0.19(3.25)$ & $0.34 * *(0.15)$ \\
\hline 4. GDP of China/Vietnam & $2.31^{* * *}(0.42)$ & $2.10^{* * *}(0.73)$ \\
\hline 5. GDP of FDI home country & $0.65^{* * *}(0.28)$ & $0.76^{*}(0.41)$ \\
\hline 6. GDP per capita of China/Vietnam & $0.79(0.67)$ & $0.54(0.66)$ \\
\hline 7. GDP per capita of FDI home country & $0.11(0.15)$ & $0.87^{* * *}(0.25)$ \\
\hline 8. Geographical distance & $-1.62^{* *}(0.59)$ & $-2.64 * * *(0.51)$ \\
\hline 9. Trade openness of FDI home country & $0.00(0.00)$ & $8.96 \mathrm{e}-11^{* * *}(9.74 \mathrm{e}-11)$ \\
\hline 10. Average monthly wages & $1.17(1.13)$ & $1.85(2.01)$ \\
\hline 11. Financial development of China/Vietnam & $0.53(5.98)$ & $-1.16(1.62)$ \\
\hline 12. Real exchange rate & $0.19 * * *(0.06)$ & $0.28^{* * *}(0.05)$ \\
\hline 13. KAOPEN index of FDI home country & $0.34^{* * *}(0.11)$ & $-0.16^{*}(0.09)$ \\
\hline 14. KAOPEN index of China/Vietnam & - & $1.15(2.34)$ \\
\hline 15. Average inflation of China/Vietnam & $-0.03(0.06)$ & $0.05^{* *}(0.02)$ \\
\hline 16. ICRG score of China/Vietnam & $1.95^{* * *}(0.73)$ & $0.32^{* *}(0.19)$ \\
\hline 17. Crisis dummy & $-0.40 * * *(0.02)$ & $-0.36^{* * *}(0.03)$ \\
\hline 18. Bilateral trade agreement & $-0.49(0.69)$ & $0.43^{*}(0.21)$ \\
\hline 19. WTO & $-0.79(1.40)$ & $1.39 * * *(0.48)$ \\
\hline 20. Contiguous border & $1.13(1.45)$ & $2.88(2.77)$ \\
\hline Constant & $39.45(124.96)$ & $-37.50(147.42)$ \\
\hline Cragg-Donald Wald F-statistic & 5.576 & 5.551 \\
\hline F-statistic & $(4.58)^{\mathrm{a}}$ & $(4.58)^{\mathrm{a}}$ \\
\hline Sargan Statistic & 0.000 & 0.000 \\
\hline P-value of Sargan test & $\begin{array}{c}{[1.000]} \\
\text { (Equation exactly identified) }\end{array}$ & $\begin{array}{c}{[1.000]} \\
\text { (Equation exactly identified) }\end{array}$ \\
\hline
\end{tabular}

Notes: Values in brackets are P-values. Values in parentheses are robust standard errors. ***, **, Significant at 1 percent, 5 percent, 10 percent level, respectively. ( $)^{a}$, Critical value of 15 percent maximal IV size proposed by Stock and Yogo (2002).

\section{Inward FDI to China: creation or diversion effect on Vietnam's inward FDI?}

To this end, we turn our attention to the question of whether China competes against Vietnam in attracting FDI inflows. Our simple answer is "No", as both the HTM and IV estimators reveal that China's inward FDI does not reduce FDI flows into Vietnam. This finding seems to be relatively consistent with the recent development of FDI theory. In light of the FDI literature, an increase in inward FDI to a country does not necessarily cause a decline in inward FDI to other ones. As suggested by Ernst (1997), transnational 
corporations (TNCs) have progressively adopted their international strategies towards systemic globalization. In this context, to fully reap the benefits of systemic globalization, the location decisions of TNCs are due to industrial structure or specification of host economies. Inward FDI to one country, therefore, may result in a creation effect on inward FDI to other ones if it creates more opportunities for international production network or a rising demand for primary and intermediate inputs. In China, investment liberalization effectively facilitates TNCs' rationalization of their production processes within East Asian region (Ianchovichina and Walmsley, 2005). As a result, China's neighbours may receive FDI inflows, which are a complement to those into China.

However, it is noteworthy that the performance of China, compared to Vietnam, in macroeconomic stability and institutional quality may become a comparative advantage of China in attracting inward FDI in the long-run, even though our empirical work finds no direct and clear-cut diversion effect of inward FDI flows to China on those to Vietnam. Precisely, the difference between China and Vietnam in the institutional dimension and quality and in the macroeconomic stability is demonstrated by a set of variables provided by the World Bank Governance Indicators:

- In terms of Rule of law: Both China and Vietnam are in the negative zone (below the average country) on the rule of law. However, Vietnam is slightly weaker than China in this measure $(-0.38$ versus -0.33 , in 2008); 5

- In terms of Corruption control: Corruption is a serious problem in China and Vietnam as both countries are in the negative zone of the World Bank control of corruption indicator. However, this problem is much more severe for Vietnam than China (-0.68 versus -0.46 , in 2008);

- In terms of Regulatory quality: This measure in both countries is weak and falling in the negative zone. However, China is significantly stronger than Vietnam $(-0.15$ versus -0.52 , in 2008); 6

- In terms of Government effectiveness: Regarding to this measure, China experiences a figure much stronger than that of Vietnam $(0.15$ versus -0.16 , in 2008); 7

- In terms of Inflation control: as reported in Table 4, while China has kept inflation low, Vietnam's inflation rate has been still higher than its economic growth even remained in two digits over the recent period.

\footnotetext{
5 Rule of law was defined by the as "the extent to which agents have confidence in and abide by the rules of society, including the quality of contract enforcement, property rights, the police, and the courts, as well as the likelihood of crime and violence" (Kaufmann et al., 2007).

6 Regulatory quality is defined as "the ability of the government to provide sound policies and regulations that enable and promote private sector development" (Kaufmann et al., 2007).

7 Government Effectiveness is defined as "the quality of public services, the capacity of the civil service and its independence from political pressures; the quality of policy formulation" (Kaufmann et al., 2007).
} 


\begin{tabular}{|c|c|c|c|}
\hline & China & Vietnam & $\begin{array}{c}\text { Time-lag } \\
\text { (Vietnam-China) }\end{array}$ \\
\hline \multirow[t]{2}{*}{$\begin{array}{l}\text { Launch of economic } \\
\text { reforms }\end{array}$} & $\begin{array}{l}\text { In December } 1978 \text { at the } \\
\text { Third Plenum of the } 11^{\text {th }}\end{array}$ & $\begin{array}{l}\text { In December } 1986 \text {, at the } \\
6^{\text {th }} \text { Congress of }\end{array}$ & \\
\hline & $\begin{array}{l}\text { Central Committee, } \\
\text { Deng Xiaoping } \\
\text { announced the official } \\
\text { launch of the Four } \\
\text { Modernizations. }\end{array}$ & $\begin{array}{l}\text { Vietnamese Communist } \\
\text { Party, Nguyen Van Linh } \\
\text { announced the official } \\
\text { launch of Vietnam's } \\
\text { economic "Renewal". } \\
\text { dubbed as "Renews, }\end{array}$ & 8 years \\
\hline $\begin{array}{l}\text { Investment } \\
\text { openness }\end{array}$ & $\begin{array}{l}\text { Law on Sino-foreign } \\
\text { joint ventures, } 1979\end{array}$ & $\begin{array}{l}\text { Foreign Investment Law, } \\
1987\end{array}$ & 8 years \\
\hline The BTA with the US & July 1979 & December 2001 & 22 years \\
\hline WTO accession & December 2001 & January 2007 & 5 years \\
\hline
\end{tabular}

On the whole, Vietnam has lagged behind China not only in the pace of adopting the globalization process (as summarized in Table 5) but also in stabilizing the domestic macroeconomic conditions and improving the institutional quality as well. It has become a significant factor responsible for the divergence in inward FDI attractiveness between China and Vietnam.

\section{Conclusion}

Using two panel datasets over the period 1994-2008 and employing two augmented gravity equations, the present paper provides an important insight into the determinants of inward FDI to China and Vietnam. Furthermore, this paper also sheds light on similarities as well as differences in the main factors determining inward FDI to China and Vietnam. In this regard, our empirical research detects a number of important findings.

Firstly, we reveal that China and Vietnam shares many common determinants of inward FDI such as the country size (measured as GDP level of FDI home and host countries), the geographic distance; and the changes in exchange rate. Secondly, bilateral trade influences inward FDI into China and Vietnam differently. While China's FDI motivations can be strongly explained by the country's export growth performance, a rising trend in Vietnam's imports is one of main factors determining its inward FDI. Thirdly and interestingly, the financial openness setting (measured as the KAOPEN index) of FDI home countries seems to only favour FDI flows into China. Fourthly, the BTA implementation or the WTO membership has only significantly positive impact on encouraging FDI flows into Vietnam. Lastly but most importantly, compared to China, 
Vietnam has experienced the weaknesses in improving institutional quality (measured as the ICRG score) and in maintaining domestic macroeconomic stability (measured as inflation rate), which are also considered as a principal explanation of a widening divergence in attracting inward FDI between China and Vietnam.

Another important finding of the present study is that a growing trend in inward FDI to China does not play any role in diverting FDI flows into Vietnam. Yet, in a dynamic process of the globalized economic system, an unrelated economic relationship between two economies today, such as the independence between FDI inflows of China and those of Vietnam, may turn to be a related one tomorrow. Thus, in the long-run, if Vietnam continues to lag behind China in improving institutional quality and government effectiveness and in stabilising macro-economy, this will become a dominant factor driving the widening gap in inward FDI attractiveness between China and Vietnam, then creating inward FDI to China but diverting inward FDI to Vietnam.

\section{References}

Addison, T., Guha-Khasnobis, B., and Mavrotas, G., 2006. "Introduction and Overview", Special issue on FDI, The World Economy, 29(1), pp. 1-8.

Balasubramanyam, V.N., Salisu, M., and Sapsford, D. 1996. "Foreign direct investment and growth in EP and IS countries", Economic Journal, 106, pp. 92-105.

Baltagi, B.H., Demetriades, P., and Law, S.H., 2009. "Financial development and openness: Evidence from panel data", Journal of Development Economics, 89, pp.285-96.

Bergstrand, J.H., and Egger, P., 2007. "A Knowledge-and-Physical-Capital Model of International Trade Flows, Foreign Direct Investment, and Multinational Enterprises," Journal of International Economics, 73(2), pp. 278-308.

Blonigen B., 2005. "A Review of the Empirical Literature on FDI Determinants", Atlantic Economic Journal, 33(4), pp. 383-403.

Blonigen, B.A., and Piger, J., 2011. "Determinants of Foreign Direct Investment", NBER Working Paper, N.16704.

Carr, D., Markusen, J.R., and Maskus, K.E., 2001. "Estimating the Knowledge - Capital Model of the Multinational Enterprise", American Economic Review, 91(3), pp. 693-708.

Chinn, M.D., and Ito, H., 2006. 'What matters for financial development? Capital controls, institutions and interactions', Journal of Development Economics, 81, pp.163-92.

Di Giovanni, J., 2005. "What Drives Capital Flows? The Case of Cross-Border M\&A Activity and Financial Deepening", Journal of International Economics, 65(1), pp. 27-49.

Dreher, Axel, Gaston, Noel and Martens, Pim, 2008. Measuring Globalization - Gauging its Consequence, New York: Springer.

Eaton, J., and Tamura, A., 1994. "Bilateralism and Regionalism in Japanese and U.S. Trade and Direct Foreign Investment Patterns", Journal of the Japanese and International Economies, 8, pp. 478-510.

Egger, P., 2000. "A note on the proper specification of the gravity equation", Economics Letters, 66(1), pp. 25-31.

Egger, P., 2002b. "An Econometric View on the estimation of Gravity models and the calculation of Trade potentials", The World Economy, 25(2), pp. 297-312.

Eichengreen, B., and Tong, H., 2006. "Fear of China", Journal of Asian Economics, 17, pp. 226-40.

Ernst, D., 1997. "From partial to systematic globalization: international production networks in the electronics industry", Working paper, N.31997, Berkely Roundtable on the International Economy, University of California.

Grosse, R. and L. J. Trevino, 1996, "Foreign Direct Investment in the United States: an analysis by country of origin", Journal of International Business Studies, 27, pp. 139-55.

Hausman, J.A., and Taylor, W.E., 1981. "Panel Data and Unobserved individual effects", Econometrica, 79, pp. 1377-98. 
Head, K., Ries, J., 2008. "FDI as an Outcome of the Market for Corporate Control: Theory and Evidence", Journal of International Economics, 74(1), pp. 2-20.

Hood, N., and Young, S., 1984. The Economics of Multinational Enterprise, London: Longman.

Hymer, S.H., 1976. The International Operation of National Firms: A Study of Direct Investment, Boston, MA: MIT.

Ianchovichina, E., and Walmsley, T., 2005. "Impact of China's WTO accession on East Asia", Contemporary Economic Policy, 23(2), pp. 261-77.

Kaufmann, D., Kraay, A., and Massimo, M., 2007. "Governance Matters VI: Governance Indicators for 1996-2006”, World Bank Policy Research Working Paper, No.4280.

Kerr, I.A., and Peter V.M., 2000. "The determinants of Foreign Direct Investment in China", Paper presented at the $30^{\text {th }}$ Annual Conference of Economists, University of Western Australia.

Laeven, L. and Valencia, F. (2008). 'Systemic banking crises: A new database', IMF Working pper No. 08/224. Washington, DC: International Monetary Fund.

Li, X., and Liu, X., 2005. "Foreign direct investment and economic growth: an increasingly endogenous relationship", World Development, 33(3), pp. 393-407.

Liu, W-H., 2010. "Determinants of FDI inflows to China: An empirical analysis of Source country characteristics", Paper presented at Taipei International Conference on Growth, Trade and Dynamics.

Liu, X.M., Romilly, P., Song, H.Y., and Wei, Y.Q., 1997. "Country characteristics and foreign direct investment in China: A panel data analysis", Weltwirschaftliches Archiv, 133(2) pp313-29.

Mirza, H., and Giroud, A., 2004. "Regional Integration and Benefits from Foreign Direct Investment in ASEAN Countries: The Case of Vietnam", Asian Development Economic Review, 21(1), pp. 66-98.

Nguyen, N.A, and Nguyen T., 2007. "Foreign direct investment in Vietnam: An overview and analysis the determinants of spatial distribution across provinces", MPRA Paper, No. 1912.

Nguyen, N.B., and Haughton, J., 2002. "Trade Liberalisation and Foreign Direct Investment in Vietnam", ASEAN Economic Bulletin, 19(3), pp. 302-318.

OECD, 2000. "Main determinants and impacts of foreign direct investment on China's economy", Working paper on International Investment, N.2000/4.

Pan, Y, 2003, "The inflow of foreign direct investment to China: the impact of country-specific factors", Journal of Business Research, 56, 829-33.

Parker, S., Phan, V.Q., and Nguyen, N.A., 2005. "Has the U.S. - Vietnam bilateral trade agreement led to higher FDI into Vietnam?”, International journal of Applied Economics, 2, pp. $199-223$.

Pham, T.H.H., 2011. "Does WTO accession matter for the dynamics of Foreign direct investment and Trade? Vietnam's new evidence", Economics of Transition, DOI: 10.1111/j.14680351.2010.00405.x.

Rajan, R.G., Zingales, L., 2003. "The great reversals: the politics of financial development in the twentieth century", Journal of Financial Economics, 69, pp.5-50.

Stock, J. H. and Yogo, M. (2002). 'Testing for weak instruments in linear IV regression', NBER Technical Working Paper No. 284. Cambridge, MA: NBER.

Swain, N.J. and Wang, Z., 1997. "Determinants of inflow of foreign direct investment in Hungary and China: time-series approach", Journal of International Development, 9(5), pp.695-726.

UNCTAD, 2007. World Investment Report.

Wei, Y. and Liu, X., 2001. Foreign Direct Investment in China: Determinants and Impact, Edward Elgar, UK.

Zhang, K.H. (2000). Why is U.S. Direct Investment in China so Small? Contemporary Economic Policy, 18(1), 82-94.

Zhao, H., 2003, "Country factor differentials as determinants of FDI flow to China," Thunderbird International Business Review, 45, 149-69.

Zhou, Y., and Lall, S., 2005. "The impact of China's FDI surge on FDI in South-East Asia: panel data analysis for 1986-2001", Transnational Corporations, 14(1), pp. 41-65. 
Country list
Data samples

Vietnam

China

\begin{tabular}{|c|c|}
\hline Vietnam & $\begin{array}{l}\text { - Developing countries (13): China; Hong Kong-China; Japan; } \\
\text { Republic of Korea; Taiwan; Canada; Cambodia; Lao PDR; The } \\
\text { Philippines; Malaysia; Thailand; Singapore; Indonesia; } \\
\text { - Developed countries (4): United States; Australia; EU15 } \\
\text { (excluding the UK); United Kingdom }\end{array}$ \\
\hline China & $\begin{array}{l}\text { East Asia (5): Hong Kong-China; Japan; Republic of Korea; } \\
\text { Taiwan; Macao } \\
\text { - Southeast Asia (8): Cambodia; Lao PDR; The Philippines; } \\
\text { Malaysia; Thailand; Singapore; Indonesia; Vietnam } \\
\text { - European countries (17): Belgium; Denmark; UK; Germany; } \\
\text { France; Ireland; Italy; Luxembourg; Netherlands; Spain; Portugal; } \\
\text { Australia; Finland; Hungary; Norway; Romania; Sweden; } \\
\text { Switzerland; Russia. } \\
\text { - Oceanic and Pacific islands (2): Australia; New-Zealand } \\
\text { - Latin America (7): Argentina; Bolivia; Brazil; Chile; Panama; } \\
\text { Paraguay; Peru } \\
\text { - North America (2): Canada; United States }\end{array}$ \\
\hline
\end{tabular}

\section{Appendix 2: Variable Description}

\section{Gravity measures}

1. Country size

\author{
1. Country size
}

Definition

Data sources

\section{Dependent variable}

Implemented FDI flows (in log-value)
FDI position of source country to China/Vietnam (in millions of U.S. dollars)
National bureau of Statistics of China (NBS); General Statistics Office of Vietnam (GSO)
- Real GDP of FDI source country;

- Real GDP of China/Vietnam;

- Real GDP per capita of FDI source country;

- Real GDP of China/Vietnam
2. Geographic Distance
3. Contiguous border a. Contiguous border
Distance between the capital of China/Vietnam and that of FDI source country
Binary dummy indicating China/Vietnam and FDI source country are geographically contiguous
CEPII
CEPII

WDI and ADB

\section{Bilateral trade openness}

4. Bilateral exports

5. Bilateral imports
Exports from China/Vietnam to FDI source country

Imports from FDI source country to China/Vietnam
National bureau of Statistics of China (NBS); General Statistics Office of Vietnam (GSO) 


\begin{tabular}{|c|c|c|}
\hline $\begin{array}{l}\text { 6. Trade openness of } \\
\text { FDI source country }\end{array}$ & $\begin{array}{l}\text { Ratio of exports and imports to GDP at } \\
\text { constant price }\end{array}$ & WDI and ADB \\
\hline $\begin{array}{l}\text { 7. Bilateral exchange } \\
\text { rate }\end{array}$ & $\begin{array}{l}\text { Real bilateral exchange rate between } \\
\text { China/Vietnam and FDI source country: } \\
\text { calculated as the product of the nominal } \\
\text { exchange rate and relative price levels in } \\
\text { each country }\end{array}$ & IFS, WDI and ADB \\
\hline $\begin{array}{l}\text { 8. Bilateral trade } \\
\text { agreement }\end{array}$ & $\begin{array}{l}\text { Binary dummy for regional trade } \\
\text { agreement between China/Vietnam and } \\
\text { FDI source country }\end{array}$ & \\
\hline 9. WTO & $\begin{array}{l}\text { Binary dummy variable capturing the } \\
\text { impact of WTO accession of China/Vietnam }\end{array}$ & \\
\hline \multicolumn{3}{|l|}{ Domestic condition } \\
\hline 10. Level of wages & $\begin{array}{l}\text { Average wages per month of } \\
\text { China/Vietnam (in US dollar) }\end{array}$ & $\begin{array}{l}\text { Ministry of Planning and } \\
\text { Investment of Vietnam; } \\
\text { National bureau of } \\
\text { Statistics of China }\end{array}$ \\
\hline $\begin{array}{l}\text { 11. Degree of financial } \\
\text { development }\end{array}$ & $\begin{array}{l}\text { Domestic credit provided by banking sector } \\
\text { in China/Vietnam (\% of GDP) }\end{array}$ & WDI \\
\hline $\begin{array}{l}\text { 12. Degree of de jure } \\
\text { financial openness }\end{array}$ & KAOPEN index of FDI home country & Chinn and Ito (2006) \\
\hline 13. Institutional quality & $\begin{array}{l}\text { International Country Risk Guide (ICRG } \\
\text { score) }\end{array}$ & Political Risk Services \\
\hline 14. Inflation & Average annual inflation of China/Vietnam & WDI \\
\hline 15. Domestic crisis & $\begin{array}{l}\text { Dummy variable capturing the impact of } \\
\text { domestic financial shock in FDI source } \\
\text { country }\end{array}$ & $\begin{array}{l}\text { Laeven and Valencia } \\
\qquad(2008)\end{array}$ \\
\hline $\begin{array}{l}\text { Instrumental } \\
\text { variables }\end{array}$ & $\begin{array}{l}\text { Hidden Import Barriers of China, Vietnam } \\
\text { and FDI donor countries }\end{array}$ & Dreher et al., 2008 \\
\hline
\end{tabular}

